partly motivated, as some have suggested, by the need to raise more venture capital to support further experiments.

"We have made a point of stressing that there is no way that transgenic pig hearts are going to be generally available to people within less than five years," he says, adding that his company is receiving full financial backing from the pharmaceutical company Sandoz, and that "there is no public share offer in the offing".

The decision to make the results of Imutran's experiments available to the press prior to their publication in the scientific literature, he said, was based on the fact that some media stories were already appearing following a presentation to a recent conference in Amsterdam.

At the same time, White promises that the planned clinical trials at the Papworth Hospital will be carried out "under guidelines from the regulatory authorities". If such experiments do, in fact, begin next year, then such authorities will have to work swiftly; the British government, in a move which gave all the appearances of having been precipitated by the Imutran announcement, has only just agreed to set up an advisory committee to establish an ethical framework for xenotransplantation experiments.

According to an announcement by officials of the Department of Health, made unusually during the course of last week's Imutran press conference, the advisory committee will be chaired by Ian Kennedy, professor of medical law and ethics at Kings College in London.

White argues that there are no major ethical issues to be resolved concerning the principle of using animal organs for human transplantation, pointing out that pig insulin, for example, is already used to treat diabetes. More difficult, he admits, will be deciding the criteria on which patients will be selected for the experimental treatment, although even here, he feels, some patients may be prepared to accept highly experimental treatment if it is their only prospect of survival.

But the advisory committee can still expect strong reaction from animal welfare groups. Compassion for World Farming, for example, a group which has been actively engaged in issues such as the fight against the patent on the Harvard Oncomouse, has already expressed its opposition to xenotransplantation, suggesting that the solution lies increasing the number of potential human donors - as well as encouraging life-styles that reduce the need for organ transplantation in general.

Imutran officials say that they are remaining on their guard against possible protest action from animal welfare groups. They already have a herd of about 400 transgenic pigs, which are being kept in Cambridgeshire. But the precise location of the pigs is being held secret to prevent attacks from extreme animal rights groups.

David Dickson

\title{
Physicists warm to French strategy on nuclear tests
}

Paris. Seen in its broad political context, more good than harm is likely to result in the long run from France's decision to carry out a final series of nuclear tests in the South Pacific. This, at least, appears to have been one conclusion to emerge from a debate among physicists held in Paris last week on the role of scientists in the internal and public debate over nuclear weapons.

Richard Garwin, IBM Fellow Emeritus at the Thomas J. Watson Research Center in New York - and the main speaker at the meeting, organized by the French Physics Association - said that the planned series of tests is "not only acceptable, but desirable, if it leads to a zero-yield comprehensive test ban treaty".

Garwin, who was an adviser to the Los Alamos weapons laboratory between 1950 and 1993, and also to US presidents John F. Kennedy, Lyndon Johnson and Richard

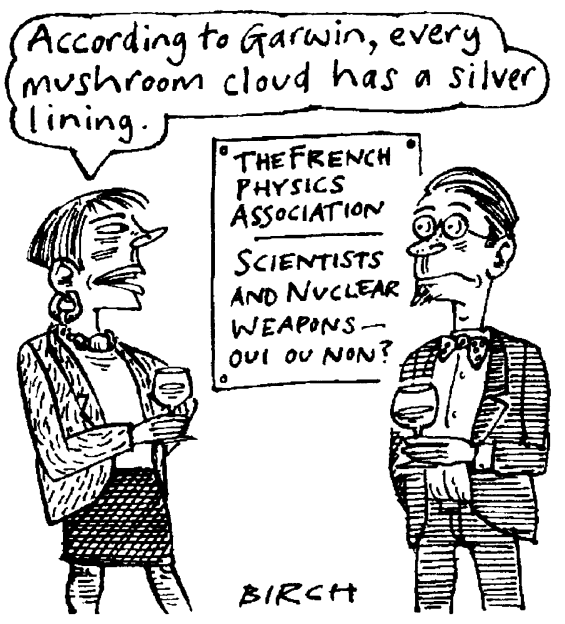

Nixon, said he was unconvinced by the French case for resuming the tests, the first of which took place two weeks ago.

But he added that, if French officials are convinced that they need the planned series of tests, then their decision to proceed will be a small price to pay for French agreement to a total test ban. There was little dissent from most of the French physicists attending the meeting, even though many had previously expressed strong criticism of the tests.

Most public attention has focused in recent weeks on the resumption of testing. But many nuclear weapons experts feel that the long-term significance of this decision may be less than that of the recent commitment by Jacques Chirac, the French president, to support a ban on all nuclear tests, no matter how small, from next year (see Nature 376, 540; 1995).

Indeed, Garwin went so far as to describe Chirac's promise, if sincere, as giving France a "leadership" role in the non-proliferation arena. He said that it has already prompted both the United States and the United Kingdom to ignore parts of their own military establishments and make similar commitments to a "zero-yield" ban.

Previously, the five nuclear weapons state members of the United Nations Security Council had been pushing for a Comprehensive Test Ban Treaty that would have allowed nuclear tests with yields up to around 1,000 tonnes (see Nature 376, 283; 1995). This socalled 'threshold' posed a greater threat to non-proliferation efforts than the French nuclear tests, argues Hubert Reeves, an astrophysicist at the Centre National de la Recherche Scientifique.

Reeves, who attended last week's meeting, has been an outspoken opponent of France's decision to resume nuclear testing. But he now says that he is "less worried" than previously about the consequences of the French decision.

According to Reeves, Chirac's commitment to a zero-yield test ban has dispelled much of the distrust created among nonnuclear weapons states by his earlier announcement to resume testing. $\mathrm{He}$ describes the gathering momentum for a total test ban as "a happy ending", and points out that this was probably influenced by the scale of public protests at French tests. "Something good always comes out of something bad", he says.

The decision to invite Garwin to be the main speaker at last week's meeting reflects the fact that US scientists have ironically played a bigger role in the internal debate in France over the decision to resume nuclear testing than the country's own scientists.

Controversy was generated earlier this summer, for example, by a joint report written by members of the US National Resources Defense Council (NRDC) and the Federation of American Scientists (FAS) - of which Garwin is vice-president - disputing the French government's justification for the planned tests.

In particular, the report argued that there was a contradiction between French claims that the existing arsenal was reliable and that two tests were needed to maintain the stockpile against the effects of ageing.

The report stimulated a lively exchange in the French press between Garwin and Jacques Bouchard, the director of the Military Applications Division of the French Atomic Energy Commission.

French scientists have obtained more than 2,000 signatures for a petition denouncing the French tests. But Reeves and others agree they have had a lower profile in the debate than their US counterparts. "I said to my colleagues, where's the spirit of '68?", says Reeves.

Declan Butler 